\title{
AUTHOR INDEX \\ VOLUME 48, 2006
}

Alveirinho Dias JM. See Monge Soares AM, 45

Anderson A. Response to Beavan Athfield's "Comment on 'Diet-Derived Variations in Radiocarbon and Stable Isotopes: A Case Study from Shag River Mouth, New Zealand' ", 241

Anderson Jr RW. Southern Palestinian Chronology: Two Radiocarbon Dates for the Early Bronze Age at Tell el-Hesi (Israel), 101

Austin WEN. See Cage AG, 31

Bartolomei P. See Magnani G, 167; See also Magnani G, 473

Bazaliiskii VI. See Weber AW, 127

Beavan Athfield N. Comment on "Diet-Derived Variations in Radiocarbon and Stable Isotopes: A Case Study from Shag River Mouth, New Zealand”, 117

Beramendi-Orosco LE. Radiocarbon Laboratory at the National Autonomous University of Mexico: First Set of Samples and $\mathrm{New}^{14} \mathrm{C}$ Internal Reference Material, 485

Beukens RP. See Weber AW, 127

Bhushan R. See Tiwari M, 17

Black SM. See Cook GT, 305

Billett MF. A Direct Method to Measure ${ }^{14} \mathrm{CO}_{2}$ Lost by Evasion from Surface Waters, 61

Boaretto E. See Lengyel G, 253

Bronk Ramsey C. See Higham TFG, 179

Buchholz BA. See Getachew G, 325

Burr GS. See Tiwari M, 17

Burri BJ. See Getachew G, 325

Buzinny M. Radioactive Graphite Dispersion in the Environment in the Vicinity of the Chernobyl Nuclear Power Plant, 451

Cage AG. Marine Radiocarbon Reservoir Ages in Scottish Costal and Fjordic Waters, 31

Carmi I. Review of The Bible and Radiocarbon Dating: Archaeology, Text and Sciences, 299

Carson MT. Radiocarbon Chronology of Prehistoric Campsites in Alpine and Subalpine Zones at Haleakalā, Maui Island, USA, 227

Chang FQ. See Zhang HC, 109; See also Zhang HC, 219

Cheng L. See Leavitt SW, 205

Cheoun MK. See Kim JC, 259; See also Kim JC, 267

Chunhai H. See Zhou W, 285

Clifford AJ. See Getachew G, 325

Connolly TJ. See Moss ML, 237

Cook GT. A Preliminary Assessment of Age at Death Determination Using the Nuclear Weapons Testing ${ }^{14} \mathrm{C}$ Activity of Dentine and Enamel, 305

Culleton BJ. Intrashell Radiocarbon Variability in Marine Mollusks, 387

Davis LG. Response to Moss et al. "An Early Holocene/
Late Pleistocene Archaeological Site on the Oregon Coast? Comments on Hall et al. (2005)”, 469

de Andrade Lima LRP. Radiocarbon Dating Sites of Itaparica Dam, São Francisco River Valley, Brazil, 459

Dijs IJ. Quantitative Determination by ${ }^{14} \mathrm{C}$ Analysis of the Biological Component in Fuels, 315

Ding H. See Zhang HC, 109

Drosg R. See Steier P, 69

Dunbar E. See Cook GT, 305

Erlandson JM. See Moss ML, 237; See also Culleton BJ, 387

Fabre L. See Lengyel G, 253

Fan HF. See Zhang HC, 109; See also Zhang HC, 219

Fedi M. See Steier P, 69

Finkelstein I. ${ }^{14} \mathrm{C}$ and the Iron Age Chronology Debate: Rehov, Khirbet En-Nahas, Dan, and Megiddo, 373

Flood Page SR. See Guilderson TP, 1

Garnett MH. See Billett MF, 61

Geertsema M. See Jull AJT, 435

Gerstmann U Ch. Determination of ${ }^{90} \mathrm{Sr} /{ }^{90} \mathrm{Y}$ in Wheat Grains, Soil, and Deposition Samples by TBP Extraction and Cerenkov Counting, 197

Getachew G. How to Convert Biological Carbon into Graphite for AMS, 325

Gonzalez-Hernandez G. See Beramendi-Orosco LE, 485

Goriunova OI. See Weber AW, 127

Govoni C. See Magnani G, 167

Guilderson TP. Seawater Radiocarbon Evolution in the Gulf of Alaska: 2002 Observations, 1

Gunji S. See Sakurai H, 401

Haack KW. See Getachew G, 325

Hagens G. Testing the Limits: Radiocarbon Dating and the End of the Late Bronze Age, 83

Hall RA. See Davis LG, 469

Harbottle G. Letter to the Editor, 123

Hardie SML. See Billett MF, 61

Hartmann K. See Zhang HC, 219

Heinemeier J. See Cage AG, 31

Higham TFG. AMS Radiocarbon Dating of Ancient Bone Using Ultrafiltration, 179; See also Anderson A, 241

Hooghiemstra H. See Tonneijck FH, 337

Hughes J. See Leavitt SW, 205

Hunter RD. See Leavitt SW, 205

Ingram BL. See Culleton BJ, 387

Jacobi RM. See Higham TFG, 179

Jansen B. See Tonneijck FH, 337

Jull AJT. See Tiwari M, 17; From the Editor, v(2); From 
the Editor, v(3); Over 16,000 Years of Fire Frequency Determined form AMS Radiocarbon Dating of Soil Charcoal in an Alluvial Fan at Bear Flat, Northeastern British Columbia, 435

Kahn JG. Society Islands (Central Eastern Polynesia) Chronology: 11 Radiocarbon Dates for the Late Prehistoric Expansion and Proto-Historic Periods in the 'Opunohu Valley, Mo'orea, 409

Kaihola L. See Dijs IJ, 315

Kang J. See Kim JC, 259; See also Kim JC, 267

Kato W. See Sakurai H, 401

Kelly PB. See Getachew G, 325

Kennett DJ. See Culleton BJ, 387

Kim IC. See Kim JC, 259; See also Kim JC, 267

Kim JC. Seoul National University Accelerator Mass Spectrometry (SNU-AMS) Radiocarbon Date List I, 259; Seoul National University Accelerator Mass Spectrometry (SNU-AMS) Radiocarbon Date List II, 267

Kim S-H. See Getachew G, 325

Kutschera W. See Steier P, 69

Kuzmin YV. Review of Environmental Archaeology: Theoretical and Practical Approaches, 295

La Torretta T. See Magnani G, 167; See also Magnani G, 473

Lange T. See Leavitt SW, 205

Leavitt SW. Henry N Michael Obituary, vii(2); Climate in the Great Lakes Region Between 14,000 and 4000 Years Ago from Isotopic Composition of Conifer Wood, 205

Lei GL. See Zhang HC, 109; See also Zhang HC, 219

Lengyel G. New AMS ${ }^{14} \mathrm{C}$ Dates from the Early Upper Paleolithic Sequence of Raqefet Cave, Mount Carmel, Israel, 253

Li B. See Zhang HC, 109

Lin L. See Zhou W, 285

Magnani G. ENEA Radiocarbon Measurements I, 167; ENEA Radiocarbon Measurements II, 473

Marino EC. See Magnani G, 167; See also Magnani G, 473

Meijer HAJ. High-Accuracy ${ }^{14} \mathrm{C}$ Measurements for Atmospheric $\mathrm{CO}_{2}$ Samples by AMS, 355

Micó R. Radiocarbon Dating and Balearic Prehistory: Reviewing the Periodization of the Prehistoric Sequence, 421

Ming QZ. See Zhang HC, 219

Mintmier MA. See Carson MT, 227

Modrow J. See Getachew G, 325

Monge Soares AM. Coastal Upwelling and Radiocarbon-Evidence for Temporal Fluctuations in Ocean Reservoir Effect off Portugal During the Holocene, 45 Moran J. See Leavitt SW, 205

Morton-Bermea O. See Beramendi-Orosco LE, 485

Moss ML. An Early Holocene/Late Pleistocene Archae- ological Site on the Oregon Coast? Comments on Hall et al. (2005), 237

Moy C. See Guilderson TP, 1

Niu J. See Zhang HC, 109

Ognibene TJ. See Getachew G, 325

Olsson IU. Comments on Sveinbjörnsdóttir et al. (2004) and the Settlement of Iceland, 243

Panyushkina IP. See Leavitt SW, 205

Park JH. See Kim JC, 259; See also Kim JC, 267

Peng C. See Zhou W, 285

Pertuisot MH. See Meijer HAJ, 355

Piasetzky E. See Finkelstein I, 373

Pranschke F. See Leavitt SW, 205

Quay PD. See Guilderson TP, 1

Ramesh R. See Tiwari M, 17

Roark EB. See Guilderson TP, 1

Ronen A. See Lengyel G, 253

Sakurai H. ${ }^{14}$ C Dating of $~ 2500$-yr-old Choukai Jindai Cedar Tree Rings from Japan Using Highly Accurate LSC Measurement, 401

Savel'ev NA. See Weber AW, 127

Schiffer MB. Review of Archaeology in Practice: A Student Guide to Archaeological Analyses, 177

Schneider AF. See Leavitt SW, 205

Schock M. See Steier P, 69

Somayajulu BLK. See Tiwari M, 17

Song YM. See Kim JC, 259; See also Kim JC, 267

Southon JR. See Culleton BJ, 387

Steier P. Radiocarbon Determination of Particulate Organic Carbon in Non-Tempered, Alpine Glacier Ice, 69

Stieglitz R. See Leavitt SW, 205

Suzuki K. See Sakurai H, 401

Takahashi Yosuke. See Sakurai H, 401

Takahashi Yui. See Sakurai H, 401

Tasa GL. See Moss ML, 237

Tiwari M. Paleoproductivity Variations in the Equatorial Arabian Sea: Implications for East African and Indian Summer Rainfalls and the El Niño Frequency, 17

Tokanai F. See Sakurai H, 401

Tonneijck FH. Radiocarbon Dating of Soil Organic Matter Fractions in Andosols in Northern Ecuador, 337

Tschöpp V. See Gerstmann U Ch, 197

Urrutia-Fucugauchi J. See Beramendi-Orosco LE, 485

van der Borg K. See Dijs IJ, 315

van der Plicht J. See Tonneijck FH, 337; See also Meijer HAJ, 355

van der Windt E. See Dijs IJ, 315 
Verstraten JM. See Tonneijck FH, 337

Vogel JS. See Getachew G, 325

Wagenbach D. See Steier P, 69

Weber AW. Radiocarbon Dates from Neolithic and Bronze Age Hunter-Gatherer Cemeteries in the CisBaikal Region of Siberia, 127

Wengnian Z. See Zhou W, 285

Wiedenhoeft A. See Leavitt SW, 205

Wild EM. See Steier P, 69

Willis SC. See Davis LG, 469

Wünnemann B. See Zhang HC, 219

Xu S. See Cook GT, 305
Xuefeng L. See Zhou W, 285

Yang MS. See Zhang HC, 109

Youn MY. See Kim JC, 259; See also Kim JC, 267

Zhang HC. Dating Paleosol and Animal Remains in Loess Deposits, 109; Dilemma of Dating on Lacustrine Deposits in an Hyperarid Inland Basin of NW China, 219

Zhang WX. See Zhang HC, 109; See also Zhang HC, 219

Zhao X. See Zhou W, 285

Zhengkun W. See Zhou W, 285

Zhou W. The 3MV Multi-Element AMS in Xi'an, China: Unique Features and Preliminary Tests, 285 